\title{
Racial folklore, black masculinities and the reproduction of dominant racial ideologies: The case of Israel Folau
}

\begin{abstract}
This article examines the continued presence of racial folklore and the reproduction of dominant racial ideologies as presented by the media and fan interactions. The case of Israel (Izzy) Folau's time at the Greater Western Sydney Giants Australian football club is presented, utilising an analysis of the club's email communications, media coverage, and discussions by sports fans on online message boards. The analysis identifies the significance of the player's racialised body in constructions of masculinity and the extent to which it plays a role in the acceptance (or not) of an athlete. The article concludes that narratives that are constructed around athletes are fluid and often change over time or in response to sporting performances or other external influences such as a change of team.
\end{abstract}

Keywords: Australian football; ethnicity; sport; message boards; race; masculinity; racial ideology; Pacific Islander

Media reproductions of black athletes have recently been accused of "fuelling racism" through their use of racial stereotypes to frame stories (Fifield, 2018). This accusation has triggered discussions around the continued presence of racial folklores and ideologies within a number of Western societies. Despite the stances taken by a number of high-profile athletes, sport remains a conservative institution that continues to reinforce dominant ideologies linked to areas such as race, gender, and masculinities (Cleland et al., In press).

This paper investigates the continued presence of racial folklore and the reproduction of dominant racial ideologies through representations of black athletes. We examine this issue empirically, triangulating our results through an investigation of the narratives adopted by a sports club, the sporting press, and sports fans concerning the case study analysis of a highprofile sporting code-switch. This migration offered a unique opportunity to study the fluidity of racial ideologies. Our analysis provides particular insight into the climate of online sports media platforms and representations of those classed as 'others' with lower status than those of the dominant cultural group. 
In a move that generated much interest, on June $1^{\text {st }} 2010$ it was announced that Israel Folau, the (as then) highly successful Brisbane Broncos, Queensland, and Australian rugby league player, had signed for the newly-formed Greater Western Sydney (GWS) Giants Australian Football League (AFL) team (Niall and Cowley, 2010). ${ }^{\mathrm{i}} \mathrm{He}$ was signed to provide a recognisable figure for their new fans, hoping that his ability, success and standing in rugby league could be easily migrated to the AFL despite his limited experience in the sport.

Because he is from Western Sydney, and is of Tongan parentage, it was believed that Folau would act as "a beacon for his community" (ABC, 2010) enabling the AFL to attract interest from this non-traditional, culturally diverse market (AFL, 2010). While returning to the region where he was born may have had some appeal (as much of his family live in Western Sydney), he was also to be well rewarded for his potential and marketability. Reports suggested that he was to earn AU\$6 million over his four-year contract (ABC, 2012).

The AFL claimed that this signing resulted in 6,311 media items in the first week alone, which they valued at AU\$12.3 million (AFL, 2010). He was heavily utilised in marketing efforts and was the best-known player in the GWS squad. A combination of his marketing role with the club, and the media fixation on his move, meant that Folau was frequently the focus of attention. In the lead-up to the GWS Giants' first game in the AFL against the Sydney Swans, in March 2012, much of the discussion on fan forums, and media speculation, revolved around him. This focus was, in part, driven by marketing activities that featured him prominently on promotional billboards and in email communications. On one billboard, displayed around Sydney at the time, he appeared alongside the leading Swans' player Adam Goodes (see Figure 1). This move was bold, as Goodes had been selected as a member of the Indigenous Team of the Century, was twice voted the best player in the AFL, and an AFL Premiership winner. Placing a player who was yet to feature in an AFL match alongside someone of this pedigree not only raised the profile of Folau, but also heightened the expectations around him.

\section{INSERT FIGURE 1 HERE}

His on-field success, however, did not match the hyperbole, and he left the club at the end of 2012 with his only season in the AFL ranking him $415^{\text {th }}$ out of 416 AFL players to have played more than ten games (News Limited, 2012). Rather than returning to rugby league, Folau opted for a third football code and signed to play rugby union. This move was 
(initially) much more successful and he was selected for the Australian Wallabies team during his first season and represented Australia at the 2015 Rugby World Cup.

\section{Black Masculinities}

Sport has been regarded as one of the last bastions of male hegemony, and a defence against a perceived 'effeminising' of society (Clayton and Harris, 2009). Australia has become increasingly urbanised, and sport is often projected as one mechanism through which a softening urban lifestyle may be warded off, keeping men both 'manly' and 'masculine' (Phillips, 2000). According to Moss (2011: 165), sport serves as one of the "primary ways in which traditional forms of masculinity has [sic] been measured". It is still seen as helping boys learn how to be men, while providing males with a reassuring all-male environment in which to socialise and bond. Sports, especially those based on physical contact, teach young males how to use their bodies as weapons against their opponents, reinforcing the importance of a strong masculine physique (Messner, 2007). Sport has become central in establishing and demonstrating hegemonic masculinity (which Connell (2005: 77) defines as the "configuration of gender practice which embodies the currently accepted answer to the problem of the legitimacy of patriarchy, which guarantees...the dominant positions of men and the subordination of women"), particularly through school systems and competitive sport (Burgess et al., 2003; Hargreaves, 1986; Smith and Beal, 2007). In some Australian schools, especially in Victoria and South Australia, Australian football has been shown to both construct and celebrate hegemonic masculinity (Connell, 2005; Engebretson, 2006).

Masculinity and ethnicity are frequently linked in sport. Connell (2005: 80) argues that race relations are a key part of the dynamics between competing masculinities with, for example, "black sporting stars becom[ing] exemplars of masculine toughness". The bodies of black athletes are particularly lauded in the media and presented as aspirational role models for young black males (Cashmore, 2005). Yet these exemplars have implications for the acceptance of black athletes and are indicative of racial bias (Hylton, 2018).

Sport journalists and broadcasters have historically 'promoted' racial differences through their coverage of sporting performances (McDonald, 2010). Although there is increased awareness of the impact of such essentialist thinking, media images continue to emphasise the success of black athletes, and thus position sport as the idealised or the only career path for young black people (Hardin et al., 2004). Hoberman (1997: 5) says that the sport-fixation 
on African Americans (and other minority groups) is part of a "global racial folklore" that foregrounds black physical and athletic superiority. Athletic black bodies are 'hyper-visible' in global media culture (Carrington, 2010), but although the black male athlete may be idolised, they are routinely reduced to stereotypical views of their body alone (Chon-Smith, 2014). As a result of this 'folklore' black male athletes have increasingly been objectified and sexualised and are presented as models of "hyper-blackness" (Whannel, 2008: 197). Sporting performances are often 'seen' in racialised terms with success (and failure) explained in terms of skin colour (Coakley, 2009). The white skin of an athlete is rarely highlighted (and is essentially invisible), whereas the skin colour of a black athlete continues to be cited (albeit possibly unconsciously) as a determining factor of ability. Whiteness is typically the norm against which all others are measured, with 'others' subject to racial liminality, marginalised from white spaces, and required to accommodate the dominant cultural preferences and norms, (Hylton, 2018). Thus, skin colour continues to play a greater role in the lives of many black athletes than it does in that of white athletes (Lawrence, 2005).

While those who govern and administer sport may wish to believe that sport is 'colour-blind' and fair across racial/ethnic divides (Cleland and Cashmore, 2014; Hylton, 2018), a number of sports, including ice-hockey, motor racing, alpine sports, swimming and volleyball, continue to be dominated by white athletes (Melnick, 2001). In sports that have greater participation rates among black athletes, there is also evidence that these athletes are excluded from central playing positions or those positions that carry the most influence on the outcomes of matches (Cashmore and Cleland, 2011; Coakley et al., 2011; Hallinanet al., 1999; Perchot et al., 2015). In one seminal study in this field, Loy and Elvogue (1970) found evidence that black athletes, because they were not linked to the white-dominated administrative structures, were relegated to peripheral positions in baseball and American football, and so did not have high levels of interaction with their teammates. These patterns in players' positions are indicative of deeply ingrained ideological beliefs of the relative merits of white and black athletes, based on the premise that pseudo-biological, racial characteristics can be used as determinants of psychological or athletic ability. While white athletes are believed to be suitable for 'thinking' and leadership positions, for instance, black athletes are believed to be "especially good at running and catching" (Coakley et al., 2011: 297).

Australia is not immune to racial stereotyping and has witnessed a number of instances of racial vilification, including an incident where a banana was thrown at Aboriginal player 
Eddie Betts in 2016 and the mass booing of Adam Goodes after he reported a 13-year old girl for calling him an 'ape' during a game in 2013. (Cleland et al., In Press; Hallinan and Judd, 2009; Klugman and Osmond, 2013, Parry, 2015; Reeves et al., 2015; Tatz, 1995). It is the intention of this article to present the case of Israel Folau, detailing the narratives that have been constructed around him and the significance of his racialised body in his acceptance as an athlete.

\section{Method}

To gain an understanding of the narratives surrounding Folau, a netnographic approach that encompassed a number of virtual spaces and methods of analyses was utilised. Netnography offers a contemporary approach to data collection that allows the researcher to take part in online fieldwork in order to study cultures and communities and their interactions in virtual spaces (Kozinets, 2010). There were a number of steps in our research approach that align with the methodological procedures outlined by Kozinets (2006) including: making entrée; data collection and analysis; trustworthy interpretation of the data and conducting ethical research. The forum data collected for our article was archival, available in digital spaces rather than requiring interaction from the researcher. While Kozinets (2006) advocates researcher participation in netnography, a complete observational, unobtrusive method was chosen and participants were thus unaffected by the actions of the researcher. The primary researcher adopted the role of a 'lurker' (Mkono and Markwell, 2014) within virtual space and therefore took part in an observational research process, becoming an active viewer rather than a contributor to the discussion. Through this process, data emerges and is captured through researcher observation, giving access to data in a flexible and iterative manner (Kozinets et al., 2014). Reid and Duffy (2018: 226) refer to netnographic sensibility through listening to the social commentary and interaction occurring in virtual spaces that allows a researcher to adopt naturalistic techniques that are "immersive and not intrusive".

Making entrée refers to the identification of research questions and selecting the appropriate spaces for study. The primary researcher acted as an insider to the data collection process, had access to the forums of study, and was signed up to the Giants member e-mail system. Data collection took place throughout 2012 and was obtained from three primary sources 1) e-mail correspondence from the club to fans (including text and images); 2) media reports from two leading newspapers; and 3) information from fan interaction within two social media communities or fan forums. 
The first data set consisted of 204 emails from the Giants to club members (fans). Emails were read through (and links clicked on) to identify discussions pertaining to Israel Folau, with relevant emails saved for further analysis. Emails were initially coded before analysis took place. The images from these emails were analysed following the guidelines set out by Jones (2015). This image analysis method has primarily been adopted to examine the gendered representation of women athletes when compared to their male counterparts. However, the inclusion of image analysis in the current study offered an additional lens through which to critically examine the representation of an athlete of colour and to explore how media outlets can manipulate/present images when communicating a key message to fans and followers of sport. Images were analysed for depictions of active and passive poses. Active images include those taken within the competitive arena depicting dynamic movements and capture the athlete in action either competing or about to compete. Passive images capture the athlete in a motionless or static state. This could include head shots of the athlete posing for a camera or images unrelated to their competitive event away from the field of play.

The (mainly) sports sections of the two best-selling Sydney-based newspapers, the Sydney Morning Herald (SMH), a 'quality' broadsheet that became a tabloid in 2013, and The Daily Telegraph, which is a traditional popular tabloid newspaper, were also analysed. The latter is strongly associated with rugby league, describing itself as the "authority on NRL" (News Corp 2015) and features a weekly 'League Central' section. The SMH claims to offer unbiased sports journalism across every major sporting code and, unlike The Daily Telegraph, has a dedicated AFL section. Search engines on the newspaper's websites and via the lead author's University's library page were used to find news stories that referred to 'Israel Folau'.

Two fan forums were identified as being the most commonly used sites for AFL-related discussions. The first forum, hereafter Forum A, in addition to having a specific section for the Giants, also had threads (collections of posts discussing a topic, typically presented in chronological order) for every player to have played for the club. The thread for Israel Folau proved the initial starting point for analysis of fan-generated discussions. In addition, 1,084 threads within the main GWS Giants-related forum were searched for references to Folau. A total of 170 threads were searched on the second forum, hereafter Forum B, which also had a 
specific GWS Giants page. In total, 26 threads referred to Folau with 591 posts that were analysed using the processes identified below.

Ethical conduct is of primacy during online data collection, analysis and reporting. Therefore, ethical clearance was obtained for the research project from the lead researcher's University prior to the study beginning. Bertilsson (2014) says that unobtrusive netnographies enables a researcher to avoid a number of ethical difficulties. Given that the forums did not require registration to access the forums, the topics being discussed were related to Australian football and so not judged to be of a sensitive nature, and there were a large number of posts and users, we deem these forums to be public spaces (Eysenbach and Till, 2001), and that informed consent was not needed for such a passive analysis of retrospectively posted messages. However, to preserve the anonymity of posters, only the forum and the date of the post were used to identify thread posts.

Miles and Huberman (1994) suggest that there are three generic stages to qualitative data analysis; data reduction of the mass of collected data; then data display in some format so as to allow conclusions to be drawn; and conclusion drawing/verification (interpreting the findings). A progressive three-stage data coding procedure was utilised Gobo (2008). This process consisted of deconstruction (open coding), construction (axial coding), and confirmation (selective coding). Data collection took place at all three of these stages and formed part of a spiral reflexive process, situated between sampling and analysis (Gobo 2008). At each stage of coding, data collection served a different purpose, first to uncover the conventions by which the observed interactions were bounded; second (during the construction stage) to explain the interactions; and finally, to document the ideas detailed during the confirmation stage. Data from all sources were first read through and notes were made with initial comments and ideas. These notes were then transformed into initial themes, which were refined and developed through further analysis and during subsequent stages of data collection (Rapley, 2011). Following this refinement, two recurring themes emerged: body matters and ethnicity and otherness.

\section{Body Matters}

Whannel (2008) states that it has increasingly been the visual appearance of athletes that plays a significant factor in marketing them, and youthful bodies and sexuality are often the central focus of the marketing of athletes. Former English footballer David Beckham, Welsh 
rugby union player Gavin Henson, and former Russian tennis player Anna Kournikova, for example, have been commercially successful, in large part, due to their physical characteristics, and they have become recognisable outside their sports for their celebrity image and beauty (Smart 2005; Harris and Clayton, 2007). Images of Folau emphasise traditional notions of manliness and masculinity, with attention focussing on his arms and legs. The camera angles used (see Figures 2-4 below) serve to emphasise his physique and make him appear even larger than he is. In the marketing of Folau it was his physical appearance that was primarily utilised. However, unlike the athletes above his personality assumed lesser prominence in his initial portrayal in the media and in online discussions amongst fans.

To be successful, athletes typically require high levels of athletic ability (Parry 2009) and physical characteristics such as height and athleticism are amongst the statistics and qualities that the AFL uses as measures of talent identification (Kelly and Hickey, 2008). It may, therefore, not be surprising that Folau's athleticism was a recurrent theme in media coverage, and it was put forward as the AFL's key reason for approaching him to convert to Australian football (Cowley and Baumgart, 2010). For example, Folau's imposing physique emerged as a corresponding theme in newspaper coverage. Media texts highlighted his height (Cowley, 2010), overall size, physical shape (Cordy, 2012), and even the size of his hands (Niall and Cowley, 2010). Fan discussions following his signing similarly focussed on his physical attributes, as detailed below:

Folau is good at RL [rugby league] because he is a tremendous athletic talent. (Forum A, May 02, 2010, post \#18)

Izzy is 6'4 and his vertical leap is quite impressive, also he is relatively quick...He already has a developed body (Forum A, May 22, 2011, post \#1)

Given his athletic ability and physical size I don't see why he can't be a huge success. (Forum B, June 7, 2011, post \#15)

He's six four, he can jump, he can catch, he's strong and he can kick straight. (Forum A, November 23, 2011, post \#4)

Sheeds [Kevin Sheedy - head coach of the club] reckons his hands are as good as anyones below the knees... (Forum A, November 30, 2011, post \#18) 
...his leap is absolutely phenomenal. will out leap anyone in the competition at the moment (including Nic Nat [fellow player Nic Naitanui]). (Forum A, June 16, 2010, post \#1)

...he is big and strong and has a proven ability to leap and catch the ball; use this year to improve his confidence in front of goal and ability to lead, and we will have ourselves a quality full forward. (Forum A, May 15, 2010, post \#13)

He has the vertical leap to just about outmark everyone, is stronger then barry hall [a former player] circa 2005 (the strongest forward I have seen in modern footy). He is quicker off the mark then just about anyone, and would be one of the fastest in the league. (Forum A, June 21, 2011, \#18).

His assumed success was based on a combination of his "tremendous athletic talent" (Forum A, May 02, 2010, post \#18) and his physical characteristics as it was believed that he would be able to outjump or outrun other players and dominate due to his strength alone. Nonetheless, as a result of this focus on his physical attributes, Folau's body was racialised and it initially assumed more importance than other personal characteristics, as it was utilised to explain his success in sport. These representations of Folau are, therefore, indicative of the continued foregrounding of the physical and athletic superiority of black athletes (Hoberman 1997; James, 2005; Massao and Fasting, 2010).

In email communications from the club to its members, Folau was often pictured alongside more established AFL players, positioned in ways that displayed his physique and stature (see Figures $2-4$ ), with the definition of his arm muscles apparent. These pictures of him are also noteworthy because they showed him carrying the ball in a manner that was different to the way in which he had previously carried a rugby league ball. He was typically in an action pose, displaying dynamism and athleticism - as is common with images of black athletes (Hardin et al., 2004). Folau was presented as a considerable physical presence and appeared to be more physically developed than those around him. In some images, he is also foregrounded to enlarge further his physical presence, as is shown in Figure 2 below:

\section{INSERT FIGURE 2 HERE}

INSERT FIGURE 3 HERE 


\section{INSERT FIGURE 4 HERE}

During Folau's year in the AFL, his playing performances and time on-field were limited and consequently discussions shifted towards his mental characteristics. For example, the posts below make direct reference to his mental capabilities and query his ability to acquire a sufficient understanding of the sport rather than on his athletic ability. Significantly, a distinction is drawn between his physical and mental abilities, which are questioned. He is assumed to be lacking intelligence, as black athletes have previously been stereotyped (Edwards, 2000; Hylton, 2018). In one instance, his athletic ability takes on a form of its own and is separated from his conscious:

I think Folau, the athlete, will be able to get the ball and be a high-level forward. Using the ball and attaining a football brain will be the difficult areas. (Forum A, June 6, 2011, post\#3)

I'm not so worried about his ability to kick and that he hasn't kicked the ball much playing rugby league that's something that can easily be worked on at training, it's a skill he shouldn't have too much trouble picking up. But the footy smarts, the ability to read the play, know when to lead, anticipate how the ball will fall from the packs that's something he can only learn on the field during a game. That's the area that concerns me. (Forum A, June 8, 2011, post \#5)

Speaking in 2014, the head coach of the club, Kevin Sheedy said that he believed "Izzy Folau lost patience with AFL" (author observation $20^{\text {th }}$ May 2014). Similarly, in a number of online forum threads, when reference was made to his personal characteristics it was often in a negative manner. He was presented as lacking confidence (Forum A, March 06, 2011, post \#4 and March 10, 2011, post \#7), lacking dedication (Forum A, November 01, 2012, post \#1), lacking leadership ability (Forum A, June 8, 2011, post \#5), being disloyal (Forum A, January 04, 2013, post \#72), and lazy (Forum A, March 02, 2012, post \#86; Forum A, May 30, 2013, post \#4). Significantly, in the immediate aftermath of his move away from the club, 'lazy' was one of the adjectives most commonly used to describe him in these forums: 
i always knew he was too lazy to become an AFL player. he didnt like running or training in explosive NRL training. What chance was there that he would become a middle distance runner? (Forum A, November 01, 2012, post \#3)

If he's ready to just up and quit like this, he was clearly not that invested in the season. Looking back, I can only think he was a waste of a spot. (Forum A, November 1, 2012, post \#21)

i heard he was a lazy trainer BEFORE he went to AFL. i still believe he has better AFL skills than hunt [Karmichael Hunt, another NRL convert]. but hunt has a go. folau is lazy. its a good example for young blokes looking to do well as a senior. folau has all the advantages over hunt; height, weight, speed, marking ability, talent, etc. hunt just tries harder. he pushes himself. he dedicates himself. i thought hunt was too much of a meathead to become an AFL 'sophisticate'. he proved me wrong. (Forum A, November 01, 2012, post \#24)

Folau found the transition to AFL too hard, and basically stopped trying. Psychologically, Elvis had well and truly left the building some time ago. (Forum A, November 01, 2012, post \#27)

There is a clear implication that he relied on his natural athleticism rather than hard work and dedication. The frequent use of the term 'lazy' is also reflective of "long-standing, widely held, racist, and ill-informed presumption of innate, race-linked black athletic superiority and intellectual deficiency" (Edwards, 2000: 9). As noted earlier, white athletes are typically identified as hard working and determined and black athletes characterised as naturally talented but idle (Cashmore and Cleland, 2011; Coakley et al., 2011). A similar pattern emerges here for the treatment of Folau, a Pacific Islander. In addition to references to his "innate" athleticism (Lewis, 2010) in media coverage, on a number of forum posts it was suggested that Folau performed at his best when he relied on his "instinct" and his body rather than trying to think about the game, as illustrated by this example:

...in his sixth game, he had a breakthrough playing on the forward line rather than down back, against the Lions reserves at the Gabba. Folau explains he stopped "thinking" and started playing on his intuition just like he used to do in the NRL, he notes. As a result, he assisted in a number of goals and took several strong marks. "I played on instinct in that third and fourth quarter," Folau says. "I started to play a lot 
better. If I keep on doing that I think I will improve quicker over time." (Forum B, May 30, 2011, post \#1)

Folau's Polynesian heritage featured prominently in fan and media discussions of his capabilities and characteristics, and is used to explain his athletic ability. In Australia, sport can serve to act as a legitimate space for the representation of black athletes (and particularly Aboriginal peoples). The most marked example of this legitimisation is concerning Aboriginal athletes, who disproportionally feature in the AFL (Judd, 2010). Sport has been used to show "Aborigines that using their bodies is still the one and only way they can compete on equal terms with an often hostile, certainly indifferent, mainstream society" (Tatz, 1995: 54). In a similar manner, Folau's Polynesian heritage is emphasised through the photographs used by the media and club. He consequently becomes an 'acceptable face' of Australia's Tongan community, acting as a role model for others, while at the same time limiting their aspirations to sport. The foregrounding of his 'natural' ability and physique, and the demeaning treatment of his mental qualities and characteristics, particularly by fans (as discussed above), are certainly congruent with stereotypical racial views on athletes (Coakley et al., 2011). Although the Tongan community may revere him, his ethnicity had implications on his acceptance by the dominant Anglo-Celtic core of Australian society.

\section{Ethnicity and 'Otherness'}

The AFL has attempted to widen the appeal of Australian football to non-traditional markets, and in 2012 recruited ten players from diverse ethnic backgrounds to act as Multicultural Ambassadors. The players were of Brazilian, Polynesian, African and Lebanese heritage (AFL, 2012), while Indigenous players, such as Adam Goodes, have also been prominently featured in marketing material (see Figure 1). In a culturally diverse region like Western Sydney, it was hoped that athletes from ethnic minorities would attract fans from similar backgrounds. As mentioned previously, Folau was expected to act as the ambassador for the Polynesian community, but doubts over the effectiveness of his role were raised. For example, journalist Steve Gee (2010) in The Daily Telegraph perhaps unsurprisingly quotes two Polynesian rugby league players who claimed that the Polynesian community in Sydney are not interested in AFL:

"I don't think Israel signing for the AFL will make much of a difference to the Polynesian community...I've got 100 per cent faith Polynesians don't find AFL 
attractive." (Roy Asotasi (a New Zealand player of Samoan heritage) quoted by Gee 2010)

and:

"The blokes with the islander backgrounds, they love their contact sport - when I was growing up I hated AFL...it just wasn't a contact sport". (Michael Jennings (an Australian player of Tongan and Fijian descent who has previously represented Tonga) quoted by Gee, 2010)

Folau's Polynesian heritage recurs in media coverage of him (Gee, 2010; Webster, 2012). However, it also positions him as an 'other' and in some cases, resulted in assumed/stereotypical views on the Polynesian community as shown below:

Born in western Sydney with alure to the polynesian community... (Forum A, June 1, 2010, post \#14)

He made his name at Melb Storm NRL, but then tranferred to Bris Broncos so that he could be closer to his Polynesian extended family. He was homesick. So why the $\mathrm{f}^{* \wedge} \mathrm{k}$ would he heading back to Melb for the Rebels RU ????? Ditto same for GWS offer. My money is on Folau following campaigner [Karmichael Hunt] to the GCFC, his teammate at Broncos, who must have had some affect on the younger Folau. They're both polynesians, and both will opt to play for the sunny GCFC. (Forum A, May 2, 2010, post \#19)

Australians frequently position non-Anglo-Celtics as 'others'. In their semiotic analysis of Australian life, Fiske, Hodge, and Turner (1987) identified a number of markers of Australianness (a constructed notion of the 'typical' Australian, linked to Anglo-Celtic, masculine ideals), such as the accent. The concept of Australianness is ingrained within Australian society (Langer and Farrar, 2003) and there is little tolerance of deviation from the norm. The perception that an athlete may be considered as 'different' based on subtle variations in accent or appearance has implications for the presentation of athletes. References to Folau's Polynesian background certainly highlight his cultural difference from the dominant Anglo-Celtic culture and position him as a potential outsider. As such, his acceptance by Anglo-Celtic fans would be hard to achieve. On Forum A, several fans equated Australian football with Australianness, with the players believed to be representative of what 
the fans saw as the dominant demographic of the Australian population. One fan even claimed the "AFL is demographically reflected on the tv screen" (Forum A, November 05, 2012, post \#50). Interestingly, one post referred to Folau's move as a Pacific Islander (PI) experiment (echoing an earlier 'Irish experiment' within the AFL), and suggested that it was threatening the Australianness of the AFL:

...but i cant say im sorry that one of the PI experiments failed. AFL matches the australian demographic. NRL now has over $45 \%$ of pacific island kids in their under 20s comp. the NRL is flooded with big, talented PI men. i dont begrudge them their talent or opportunity. but NRL could turn it round a bit with less interchange... which they refuse to do.it will kill the game from the bottom up. juniors parents dont want their kids playing monsters. but the change for interchange is something that is inevitable in AFL. the interchange will be slashed to make athletes run more. that will keep AFL 'australian'. and free of a small population of 'explosive' athletes. it will also keep the demographic picture of the australian population reflected in AFL. not the NRL. (Forum A, November 01, 2012, post \#24)

In this extract, rugby league is identified as being increasingly dominated by players of Pacific Island descent and the fan argues for changes to the rules of Australian football to prevent a similar situation occurring. This shift in the demographic profile of players in some Australian sports was of concern to a number of contributors. Perceived racial differences between Australians of Anglo-Celtic and Pacific Island descent are from this position regarded as a threat to the history and traditions of both rugby league and Australian football:

...the interchange rule has seen islander heritage players domminate player numbers in the NRL tyo the point that $30 \%$ of players are now of islander heritage. (Forum A, May 02, 2012, post \#86)

...i wonder how many mums and dads have quietly talked their kids around from playing RL, because of the worry of getting steamrolled by PI kids $30 \mathrm{~kg}$ 's bigger. (Forum A, November 04, 2012, post \#48)

i find it pretty easy to convince parents to convert to AFL. soccer parents are easy when they find out no contact till u11s. RL are a bit harder, if their kids are doing ok. but it plants a seed. and when the boy is 14 , gets steamrolled by a $100 \mathrm{~kg}$ PI kid, that seed may sprout....(Forum A, November 05, 2012, post \#50) 
The above posts serve to reinforce racial prejudices and inequality, further privileging the dominant Anglo-Celtic culture of Australianness and normalising whiteness. Australia has a history of systemic discrimination against visible ethnic minority communities (Taylor et al., 2009), and up until the 1970s this discrimination was deeply embedded within the population and the White Australia policy (Forrest and Dunn, 2006). While such 'old racism' is now less overt, it has been replaced by a 'new racism' or 'cultural racism' that highlights cultural differences and presents ethnic minority groups as "threats to 'social cohesion' and 'national unity" (Cleland and Cashmore, 2016; Cleland et al., 2019; Markus, 2001). The derogatory comments made about Folau's personal and mental characteristics and generally towards Polynesian-Australians are further evidence of the continued presence of embedded racism within Australian sport. The historical hostility towards 'otherness' that has been present within the AFL, or at least its fans (Hallinan and Judd, 2009; Nadel, 1998; Tatz, 1995) puts Folau at odds with followers of Australian football. Indeed, our informal observations at GWS Giants games revealed that the fans appeared to be predominantly Anglo-Celtic, further serving to position Folau as an 'other'.

\section{Conclusions}

This analysis of Israel Folau has revealed much about the presentation of black athletes and offers important analytical insights into several significant areas relating to sport, adding to the scholarship on race in sport and society. As noted earlier, the male black body is often presented as the epitome of hegemonic masculinity and our analysis has revealed the enduring power of images that emphasise black masculinity. These representations have implications for the acceptance of black athletes by supporter bases that are largely AngloCeltic.

Folau's body was significant in representations of him, suggesting that physical appearance is important in the construction of narratives around Australian male athletes. In the context of sport, the dominant narratives that emerged are based on "traditional forms and norms of physical activity" that are indicative of a "culturally conservative institution" (Adair, 2009: 420). These traditional "forms and norms" often uphold masculine, white ideals connected to sports that are associated with traditional notions of Australianness, such as Australian football (Carniel, 2008; Gemmell, 2007; Hess, 2008; McKay et al., 2001). 
Folau's heritage was a key factor in his presentation, with images of him racialised. The overrepresentation of his body, we argue, is another example of what Hoberman (1997) describes as the global racial folklore that emphasises the physical characteristics of black athletes and diminishes their intellectual capabilities. By emphasising Folau's Tongan heritage, the Giants and the AFL positioned him as an 'outsider' and thus potentially at odds with the dominant Anglo-Celtic AFL culture and a potential target for racial abuse. While there has been much discussion on the vilification of Aboriginal players within Australian Rules football, there is need for further investigation into the treatment of 'others' more widely within the sport. The degree of hostility shown towards Folau, due to his heritage, is indicative of embedded cultural racism amongst some AFL fans.

Finally, this study has shown that narratives that are constructed around athletes are fluid and often change over time or in response to sporting performance or external influences such as club or code switches. At such time, dominant, stereotypical ideologies continue to be drawn upon by both the media and fans. In the case of Folau, a narrative of assumed success due to his athletic abilities gave way to a far more negative one where any personal limitations were linked to his status as an 'other'. This finding corresponds to previous analyses of his presentation in the media (Parry, 2013) where Folau's time in the AFL was subject to similarly contrasting narratives.

\section{Acknowledgements}

We would like to thank the anonymous reviewers for their insightful and helpful comments on an earlier version of this article.

\section{References}

ABC (2010) Folau Moves To AFL. ABC. Available at: http://www.abc.net.au/news/2010-0601/folau-moves-to-afl/849670 (accessed 4 April 2014).

ABC (2012) AFL Would Have Paid More For Folau. $A B C$. Available at: http://www.abc.net.au/news/2012-03-07/afl-would-have-paid-more-for-folau/3874766 (accessed 23 July 2014).

Adair D (2009) Australian Sport History: From The Founding Years To Today. Sport In History 29(3): 405-36. 
AFL (2010) Annual Report. Available at:

http://www.afl.com.au/staticfile/afltenant/afl/files/afl_annual_report_2010.pdf (accessed 1 April 2014).

AFL (2012) Annual Report. Available at:

http://www.afl.com.au/staticfile/afltenant/afl/files/aflannual report 2012_web.pdf (accessed 1 April 2014).

Bertilsson J (2014) Critical Netnography: Conducting Critical Research Online. In: Jeanes E and Huzzard T (eds) Critical Management Research: Reflections From The Field. London: Sage, pp. 137-52.

Burgess I, Edwards A and Skinner J (2003) Football Culture In An Australian School Setting: The Construction Of Masculine Identity. Sport, Education And Society 8(2): pp. 199212.

Carniel J (2008) Sheilas, Wogs And Metrosexuals: Masculinity, Ethnicity And Australian Soccer. Soccer \& Society 10(1): 73-83.

Carrington B (2010) Race, Sport And Politics: The Sporting Black Diaspora. London: Sage.

Cashman R (2010) Paradise Of Sport: A History Of Australian Sport. Petersham: Walla Walla Press.

Cashmore E and Cleland J (2011) Why Aren't There More Black Football Managers? Ethnic And Racial Studies 34(9): 1594-607.

Cashmore E (2005) Making Sense Of Sports. London: Routledge.

Chon-Smith C (2014) Yellow Bodies, Black Sweat: Yao Ming, Ichiro Suzuki, And Global Sport. Journal For Cultural Research 18(4): 291-314.

Clayton B and Harris J (2009) Sport And Metrosexual Identity: Sports Media And Emergent Sexualities. In Harris J and Parker A (eds) Sport And Social Identities. Basingstoke: Palgrave Macmillan, pp. 132-49.

Cleland J \& Cashmore E (2014) Fans, racism and British football in the 21st century: The existence of a colour-blind ideology. Journal of Ethnic and Migration Studies, 40(4): 638-654.

Cleland J \& Cashmore E (2016) Football fans' views of racism in British football. International Review for the Sociology of Sport 51(1): 27-43.

Cleland J, Parry K and Radford D (In Press) "Perhaps she only had a banana available to throw": Habitus, racial prejudice and whiteness on Australian Football League message boards. Sociology of Sport Journal.

Coakley J (2009) Sports In Society: Issues And Controversies. New York: McGraw-Hill. 
Coakley J, Hallinan C \& McDonald B (2011) Sports In Society 2: Sociological Issues \& Controversies. Sydney: McGraw-Hill.

Connell RW (2005) Masculinities. Crows Nest, N.S.W.: Allen \& Unwin.

Cordy N (2012) Israel Folau Worth Every Cent For AFL, The Daily Telegraph. Available at: http://www.dailytelegraph.com.au/sport/afl/israel-folau-worth-every-cent-for-afl/storye6frexx0-1226508678033 (accessed 3 February 2013).

Cowley M \& Baumgart S (2010) Revealed: How Kevin Sheedy And GWS Got Their Man,

The Sydney Morning Herald. Available at: http://www.smh.com.au/rugbyleague/league-news/revealed-how-kevin-sheedy-and-gws-got-their-man-20100601wrm8.html (accessed 30 January 2013).

Cowley M (2010) Kieren Jack believes Israel Folau would be a success. The Sydney Morning Herald. Available at http://www.smh.com.au/afl/afl-news/israel-ideal-for-switch-ofcodes-says-swans-jack-20100519-vfbg.html (accessed 3 April 2015).

Dunn KM, Forrest J, Burnley I \& McDonald A (2004) Constructing Racism In Australia. Australian Journal Of Social Issues 39(4): 409-30.

Edwards H (2000) Crisis Of Black Athletes On The Eve Of The 21st Century. Society 37(3): 9-13.

Engebretson K (2006) Identity, Masculinity And Spirituality: A Study Of Australian Teenage Boys. Journal Of Youth Studies 9(1): 91-110.

Eysenbach G and Till JE (2001) Ethical Issues In Qualitative Research On Internet Communities. BMJ 323(7321):1103.

Fifield D (2018) Raheem Sterling accuses media of 'fuelling racism' after alleged abuse. The Guardian. Available at: https://www.theguardian.com/football/2018/dec/09/raheemsterling-newspapers-fuelling-racism-alleged-abuse-chelsea (accessed 14 December 2018).

Fiske J, Hodge B and Turner G (1987) Myths Of Oz: Reading Australian Popular Culture. St Leonards: Allen \& Unwin.

Forrest J and Dunn KM (2006) Racism And Intolerance In Eastern Australia: A Geographic Perspective. Australian Geography 37(2): 167-86.

Gee S (2010) No AFL Culture Club Among Polynesians. The Daily Telegraph. Available at: http://www.dailytelegraph.com.au/sport/no-afl-culture-club-among-polynesians/storye6frexni-1225874764667 (accessed 3 February 2013).

Gemmell J (2007) All White Mate? Cricket And Race In Oz. Sport In Society 10(1): 33-48. Gobo G (2008) Doing Ethnography. London: Sage. 
González GL (1996) The Stacking Of Latinos In Major League Baseball: A Forgotten Minority. Journal Of Sport \& Social Issues 20(2): 134-60.

Hallinan C and Judd B (2009) Changes In Assumptions About Australian Indigenous Footballers: From Exclusion To Enlightenment. The International Journal Of The History Of Sport 26(16): 2358-75.

Hallinan CJ, Bruce T and Coram S (1999) Up Front And Beyond The Centre Line: Australian Aborigines In Elite Australian Rules Football. International Review For The Sociology Of Sport 34(4): 369-83.

Hardin M, Dodd JE, Chance J \& Walsdorf K (2004) Sporting Images In Black And White: Race In Newspaper Coverage Of The 2000 Olympic Games. Howard Journal Of Communications 15(4): 211-27.

Hargreaves J (1985) The Body, Sport And Power Relations. The Sociological Review 33(S1): 139-59.

Hargreaves J (1986) Sport, Power And Culture: A Social And Historical Analysis Of Popular Sports In Britain. London: Polity Press.

Harris J and Clayton B (2007) The First Metrosexual Rugby Star: Rugby Union, Masculinity And Celebrity In Contemporary Wales. Sociology Of Sport Journal 24( 2): 145-64.

Hess R (2008) A National Game: The History of Australian Rules Football. Camberwell: Penguin.

Hoberman JM (1997) Darwin's Athletes: How Sport Has Damaged Black America And Preserved The Myth Of Race. New York: Houghton Mifflin Harcourt.

Hylton K (2018) Contesting 'Race' and Sport: Shaming the Colour Line. Oxon: Routledge. James CE (2005) Race in Play: Understanding the Socio-Cultural Worlds of Student Athletes. Toronto: Canadian Scholars' Press Inc.

Jones I (2015) Research Methods For Sports Studies. Oxon: Routledge.

Judd B (2010) Research Reflections: Racism In Australian Football - White Australian Rules! Indigenous Law Bulletin 7(20): 3-7.

Judd B and Butcher T (2016) Beyond Equality: The Place Of Aboriginal Culture In The Australian Game Of Football. Australian Aboriginal Studies 2016: 68-84.

Kelly P and Hickey C (2008) The Struggle For The Body, Mind And Soul Of AFL Footballers. North Melbourne, Vic: Australian Scholarly Publishing.

Kent P (2010) Short-Term Gain, Long-Term Pain. The Daily Telegraph. Available at: http://www.dailytelegraph.com.au/sport/nrl/short-term-gain-long-term-pain/storye6frext9-1225874223107 (accessed 3 February 2013). 
Klugman M and Osmond G (2013) Black and Proud: The Story of an Iconic AFL Photo. Sydney: NewSouth Books.

Kozinets RV (2006) Click To Connect: Netnography And Tribal Advertising. Journal Of Advertising Research 46(3): 279-88.

Kozinets RV (2010) Netnography: Doing Ethnographic Research Online. London: Sage.

Kozinets RV, Dolbec P and Earley A (2014) Netnographic analysis: understanding culture through social media data. In Flick U The SAGE handbook of qualitative data analysis. London: Sage, pp 262-276.

Langer B and Farrar E (2003) Becoming 'Australian' In The Global Cultural Economy: Children, Consumption, Citizenship. Journal Of Australian Studies 27(79): 117-26.

Lawrence SM (2005) African American Athletes' Experiences Of Race In Sport. International Review For The Sociology Of Sport 40(1): 99-110.

Lewis D (2010) Talent Not Enough For Code Swap. The Sydney Morning Herald. Available at: $\quad$ http://www.smh.com.au/afl/afl-news/talent-not-enough-for-code-swap-20100604xkjc.html (accessed 30 January 2013).

Loy JW and Elvogue JF (1970) Racial Segregation In American Sport. International Review For The Sociology Of Sport 5(1): 5-24.

Massao PB and Fasting K (2010) Race and racism: the experiences of black Norwegian athletes. International Review for the Sociology of Sport 45: 147-162.

McDonald MG (2010) The Whiteness Of Sport Media/Scholarship. In: Hundley H and Billings AC (eds) Examining Identity In Sport Media. London: Sage, pp. 153-72.

Mckay J, Lawrence G, Miller T and Rowe D (2001) Gender Equity, Hegemonic Masculinity And The Governmentalisation Of Australian Amateur Sport. In: Bennett T and Carter D (eds), Culture In Australia: Policies, Publics And Programs, Cambridge University Press, Cambridge, pp. 233-52.

Messner MA (2007) Out of Play: Critical Essays on Gender and Sport. New York: State University of New York Press.

Miles MB and Huberman AM (1994) Qualitative Data Analysis: An Expanded Sourcebook. Thousand Oaks, Calif.: Sage

Mkono M \& Markwell K (2014) The Application Of Netnography In Tourism Studies. Annals Of Tourism Research 48: 289-91.

Moss M (2011) The Media and Models of Masculinity. Lanham, Maryland: Lexington Books. Nadel D (1998) Colour, Corporations And Commissioners, 1976-1985. In: Hess R \& Stewart B (eds) More Than A Game South Carlton: Melbourne University Press, pp. 200-24. 
News Corp (2015) Media Kit 2015. Sydney: News Corp Australia.

News Limited (2012) Izzy Or Bust In The AFL's Frontier Land. News.com.au. Available at: http://www.news.com.au/national/izzy-or-bust-in-the-afls-frontier-land/story-e6frfkp91226308691517 (accessed 5 December 2014).

Niall J \& Cowley M (2010) Western Sydney's \$4.2m Snares Folau For AFL. The Sydney Morning Herald. Available at: http://www.smh.com.au/rugby-league/leaguenews/western-sydneys-42m-snares-folau-for-afl-20100531-wrim.html (accessed 30 January 2013).

Pandaram J (2010) Izzy AFL's \$6m Polynesian Pioneer. The Sydney Morning Herald. Available at: http://www.smh.com.au/rugby-league/league-news/izzy-afls-6mpolynesian-pioneer-20100601-wvd5.html (accessed 30 January 2013).

Parramatta City Council (2012) Summary Statistics Greater Western Sydney. Parramatta: Parramatta City Council.

Parry KD (2009) Search For The Hero: An Investigation Into The Sports Heroes Of British Sports Fans. Sport In Society 12(1): 212-26.

Parry KD (2015) Booing Adam Goodes - racism is in the stitching of the AFL. The Conversation. Available at: https://theconversation.com/booing-adam-goodes-racismis-in-the-stitching-of-the-afl-45316 (accessed 29 July 2015).

Parry KD (2013) Can’t Buy Me Love: The Rise And Fall Of An AFL “Hero”. In: Hynes D,

Kiernan A and K Parry K (eds) Football And Communities Across Codes UK: InterDisciplinary Press, pp. 15-24.

Perchot R, Mangin F, Castel P and Lacassagne M-F (2015) For a socio-psychological approach of the concept of racial stacking. European Journal for Sport and Society 12(4): 377-396.

Phillips J (2000) Sport And Future Australasian Cult. The International Journal Of The History Of Sport 17(2-3): 323-32.

Rapley T (2011) Some Pragmatics Of Data Analysis. In: Silverman D (ed) Qualitative Research: Issues Of Theory, Method And Practice London: Sage, pp. 273-90.

Reeves K, Ponsford M and Gorman S (2015) Codes combined: Managing expectations and policy responses to racism in sport. Sport in Society. 18(5): 519-528.

Rogers M (2009) AFL Hopes Footy 'Seed' Will Thrive In West Sydney. AFL.com. Available at: $\quad$ http://www.afl.com.au/news/newsarticle/tabid/208/newsid/72993/default.aspx (accessed 23 January 2012). 
Rosenberg BC (2009) The Australian Football Wars: Fan Narratives Of Inter-Code And Intra-Code Conflict. Soccer \& Society 10(2): 245-60.

Smart B (2005) The Sports Star: Modern Sport And The Cultural Economy Of Sporting Celebrity. London: Sage.

Smith MM and Beal B (2007) "So You Can See How The Other Half Lives": MTV "Cribs" Use Of “The Other” In Framing Successful Athletic Masculinities. Journal Of Sport \& Social Issues 31(2): 103-27.

Sydney Thunder (2013) Nick Cummins Appointed To Lead Sydney Thunder. Cricket

Australia. Available at: http://www.sydneythunder.com.au/news/2013/08/07/nickcummins-appointed-to-lead-sydney-thunder (accessed 10 August 2013).

Tatz C (1995) Racism And Sport In Australia. Race \& Class 36(4): 43-54.

Taylor T, Lock D and Darcy S (2009) The Janus Face Of Diversity In Australian Sport. Sport In Society 12(7): 861-75.

Webster A (2012) Why Kevin Sheedy Believed Israel Folau Would Be An AFL Star. The Daily Telegraph. Available at: http://www.dailytelegraph.com.au/sport/nrl/why-kevin$\underline{\text { sheedy-believed-israel-folau-would-be-an-afl-star/story-e6frexnr-1226508643703 }}$ (accessed 30 January 2013).

Whannel G (2008) Culture, Politics And Sport: Blowing The Whistle, Revisited. London: Routledge.

Williams R (2013) “Anyone Who Calls Muse A Twilight Band Will Be Shot On Sight”: Music, Distinction, And The "Interloping Fan" In The Twilight Franchise', Popular Music And Society, Vol. 36, No. 3, pp. 327-42.

\footnotetext{
${ }^{1}$ The Western Sydney Context

The Giants were created and, to a large extent, imposed on a region that had little history of Australian football. It is historically associated with rugby league and is considered to be a heartland of the sport (Rosenberg 2009). The move to introduce a second team in Sydney was greeted with some hostility by those who feel that AFL has no place in New South Wales (NSW) (Parry 2013). GWS is a region within the metropolitan area of Sydney in the eastern Australian state of NSW. The region has a diverse ethnic make-up that includes one half of the world's nationalities, and it is home to one in eleven Australians, with the most recently fully-reported census (June 2011) revealing an estimated population of 2.02 million that is forecast to grow to over 3 million inhabitants by 2036 (Parramatta City Council 2012). The expanding population of GWS has led three of Australia's main professional sporting competitions, the A-League (association football), the Big Bash League (cricket), and the AFL to establish teams in the region since 2011. In two of these cases, the new teams have been clearly labelled as representing Sydney's West. As with the GWS Giants, the new association football team was named the Western Sydney Wanderers (our italics), and, while the second of Sydney's Big Bash teams - the Sydney Thunder - is not linked to the region by name, the club has aligned itself with it and "the people of Western Sydney" (Sydney Thunder 2013). The Sydney metropolitan region is now saturated with sports teams all vying for sport market share, including: nine of the sixteen NRL teams; two A-League teams (with corresponding women's teams); two teams in each of the men's and women's Big Bash Leagues; two teams in the Australian national netball league (starting in 2017); one Super Rugby (rugby union) team; a team
} 
in both the National Basketball League and the Australian Baseball League; two AFL teams; and, from 2017, a team in the new AFL Women's competition. 